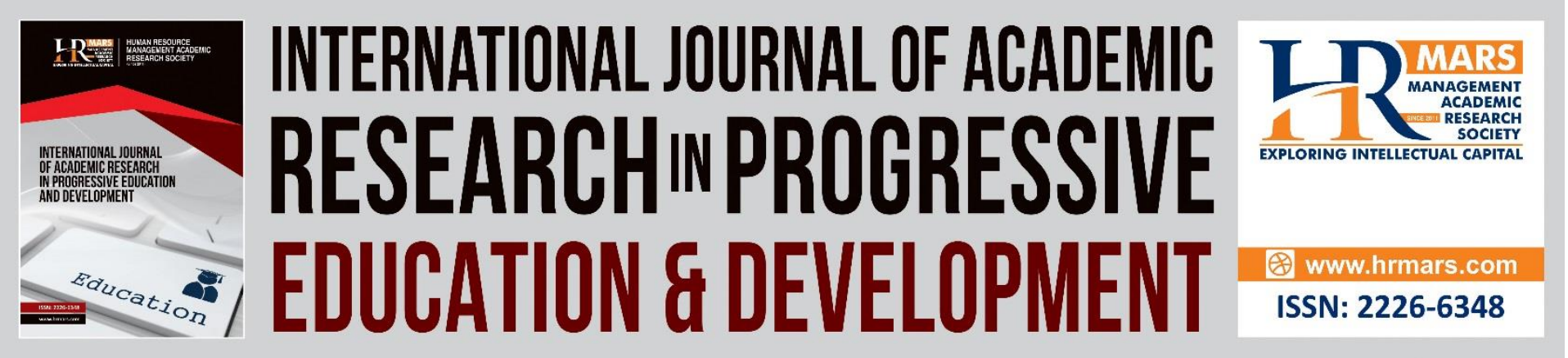

\title{
The Relationship between Pre-service Preschool Teachers' Interest and Career Choice Satisfaction in China
}

\author{
Lijuan Shen, Loy Chee Luen
}

To Link this Article: http://dx.doi.org/10.6007/IJARPED/v11-i1/11681

DOI:10.6007/IJARPED/v11-i1/11681

Received: 09 November 2021, Revised: 13 December 2021, Accepted: 28 December 2021

Published Online: 17 January 2022

In-Text Citation: (Shen \& Luen, 2022)

To Cite this Article: Shen, L., \& Luen, L. C. (2022). The Relationship between Pre-service Preschool Teachers' Interest and Career Choice Satisfaction in China. International Journal of Academic Research in Progressive Education and Development, 11(1), 310-318.

Copyright: (C) 2022 The Author(s)

Published by Human Resource Management Academic Research Society (www.hrmars.com)

This article is published under the Creative Commons Attribution (CC BY 4.0) license. Anyone may reproduce, distribute, translate and create derivative works of this article (for both commercial and non-commercial purposes), subject to full attribution to the original publication and authors. The full terms of this license may be seen at: http://creativecommons.org/licences/by/4.0/legalcode

Vol. 11(1) 2022, Pg. 310 - 318

Full Terms \& Conditions of access and use can be found at http://hrmars.com/index.php/pages/detail/publication-ethics 


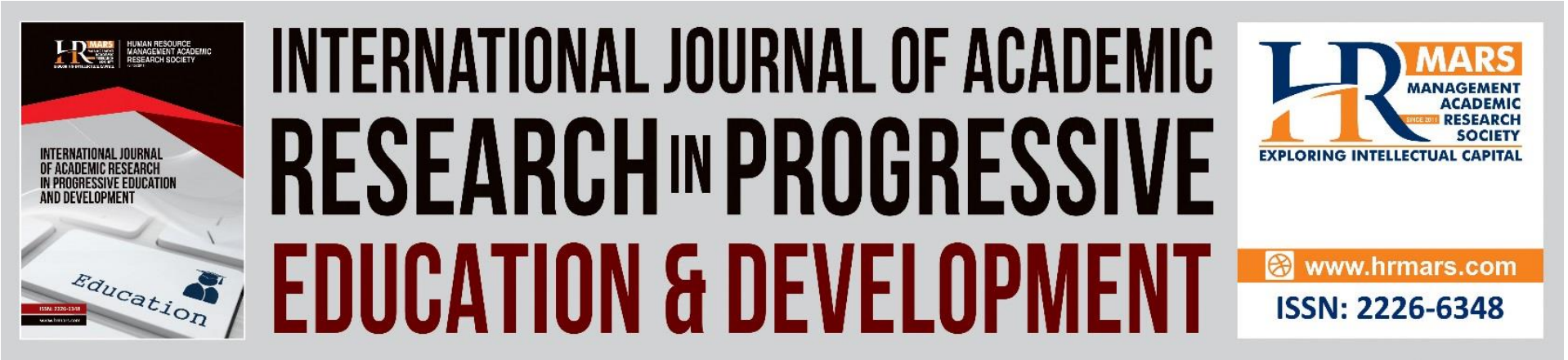

\title{
The Relationship between Pre-service Preschool Teachers' Interest and Career Choice Satisfaction in China
}

\author{
1,2Lijuan Shen, ${ }^{3}$ Loy Chee Luen
}

${ }^{1}$ National Child Development and Research Center Ipoh, Malaysia, ${ }^{2}$ Athena Institute of Holistic Wellness, ${ }^{1}$ Sultan Idris Education University, ${ }^{2}$ Wuyi University, Wuyishan, China,

${ }^{3}$ Faculty of Human Development Sultan Idris Education University Ipoh, Malaysia

Email: 360210607@qq.com, loy.cl@fpm.upsi.edu.my

\begin{abstract}
Purpose: This research aims to explore the relationship between pre-service preschool teachers' interest and career choice satisfaction, and to provide a basis for schools and teachers' two-way selection of preschool teacher positions. Methods: Using the Teacher Interest Scale (TIS) and the career choice satisfaction subscale in the FIT-Choice scale, using SPSS to conduct descriptive statistics and inferential analysis on the data of 212 pre-service preschool teachers in local undergraduate colleges. Results: The subject interest of preservice preschool teachers was significantly positively correlated with didactic interest and educational interest; educational interest was significantly positively correlated with didactic interest and career choice satisfaction.
\end{abstract}

Keywords: Pre-service Teachers, Preschool, Teacher Interests, Career Choice Satisfaction

\section{Introduction}

The quality of preschool teachers and the shortage of teachers have always been one of the key issues in the teaching profession and teacher education in many countries including China (Xiuminet et al., 2021). The fundamental reason why individuals become teachers and their personal views on the profession is increasingly attracting the interest of educational researchers (Richardson \& Watt, 2006; Watt \& Richardson, 2007). Interest can be considered as an important factor in determining career choices (Li 2011). Teachers' interest and satisfaction are key factors that significantly and positively affect students' motivation, learning, and achievement (Long \& WoolfolkHoy, 2006).

Therefore, it is important to study how pre-service preschool teachers' interests and career choice satisfaction are related to each other to provide a basis for these efforts to improve the quality of teachers. This is a key issue of concern to countries with serious teacher shortages and losses. Therefore, this research mainly focuses on the relationship between pre-service preschool teachers' interests and career choice satisfaction. The specific research questions are as follows: Are there any differences in pre-service preschool teachers of different genders, different grades, and internship experience in the dimensions of teacher 
interest and career choice satisfaction? How is the level of pre-service preschool teachers' interest and career choice satisfaction? what's the relationship between the teachers' interest and career choice satisfactioin? Are the dimensions of teaching interest and career choice satisfaction related? Four null hypotheses of the study are; (1) There is no significant difference for pre-service preschool teachers' different genders in the dimensions of teacher interest and career choice satisfaction; (2)There is no significant difference for pre-service preschool teachers' different grades in the dimensions of teacher interest and career choice satisfaction; (3)There is no any significant difference for pre-service preschool teachers' internship experience in the dimensions of teacher interest and career choice satisfaction; (4)There is no any significant relationship between pre-service preschool teachers' interest and career choice satisfaction

\section{Theoretical Framework Teacher Interest}

Teacher interest is conceptualized as personal interest, which refers to a relatively permanent attraction to certain topics or fields (such as school subjects, specific knowledge fields) (Glutsch \& König, 2019). Taking teachers' interest in teaching as a multi-dimensional structure originated from the research of researchers such as (Schiefele, Streblow \& Retelsdorf, 2013). They believe that the main aspect of the concept of teacher interest is to advocate not only interest in the content of a subject, but also interest in teaching and education, so they constructed and developed a three-dimensional teacher interest scale (TIS). These three dimensions are subject interest(SI), didactic interest (DI) and educational interest (EI). Subject interest refers to people's interest in the teaching subject (such as physics), which not only covers the content taught in the classroom (course content), but also includes various aspects of a wider range of subjects (for example, in teacher education (such as elementary school teaching). Didactic interest refers to the teacher's interest in teaching methods, literary knowledge in teaching methods, and how to best prepare teaching content. Educational interest refers to the interest in educational aspects or problems in the teaching profession. For example, this may include information about education or children's goals, imparting values and social abilities, and how to deal with students of different difficulty levels or classes of different levels)

Hence, A three-dimensional framework of teacher interest was employed in his research. When using the Teacher Interest Scale (TIS) to conduct research, scholars found that the three dimensions of teacher interest have a significant impact on teacher burnout, classroom enjoyment, and teaching strategies (Schiefele, 2017; Schiefele \& Schaffner, 2015).

\section{Career Choice Satisfaction}

The phrase "career choice satisfaction" is used in this study to describe how satisfied preservice teachers are with their teaching choices (Richardson \& Watt, 2006). The word "FITChoice" is derived mostly from the FIT-Choice framework. Career choice satisfaction is defined as an outcome variable and tested as a one-dimensional structure in this framework (Watt \& Richardson, 2007). Scholars feel that it is better suited to assessing pre-service teachers' career in one dimension than a multi-dimensional framework of teachers because the former currently lacks actual teaching experience (Eren \& Rakıcıoğlu, 2017).

FIT-Choice has been shown to be an effective and reliable framework for assessing pre-service teachers' teaching motivation, career expectations, and career choice satisfaction in a variety 
of countries, including Australia (Watt and Richardson, 2008), Ireland (Hennessy \& Lynch, 2017), and Turkey (Kilnc et al., 2012). Furthermore, Eren and Tezel (2010) investigated the relationship between pre-service teachers' future time perspective, teaching motivation, teaching career plan, and career choice satisfaction, and discovered that pre-service teachers' career choice satisfaction is significantly related to teaching motivation and teaching career plan,.

More importantly, the researchers also found that pre-service preschool teachers' interest is related to career choices (Harackiewicz et al., 2008; Musu-Gillette et al., 2015), which also confirmed that pre-service preschool teachers' interests have a positive impact on their academic studies, persistence and career choice satisfaction (Eren,2012).

\section{Method}

\section{Participants}

A total of 212 pre-service preschool teachers participated in the survey. Convenience sampling methods were used to select subjects for the survey at the institution where the researcher teaches. The selected subjects are based on the following principles: (1) Preservice preschool teachers; (2) students were enrolled in the local undergraduate college. A total of 212 questionnaires were issued in this survey, and 201 valid questionnaires were returned (recovery rate of $94.8 \%$ ), including 23 males and 178 females; 65 first-year university students, 53 second-year university students, 46 third-year university students, and 37 university students in the fourth grade separately; 83 people have internship experience and 118 people have no internship experience.

\section{Research Instruments}

\section{Teacher Interest Scale (TIS)}

The Teacher Interest Scale (TIS), originally developed by Schiefele, Streblow \& Retelsdor (2013) is used to assess pre-service teachers' interest in teaching. TIS contains three factors: subject interest (five items), didactic interest (four items) and educational interest (six items). Using the Likert 7-level scoring method, from 1 (completely disagree) to 7 (completely agree) means the higher the score, the higher the interest. The scale has good reliability and validity in previous studies. The Cronbach's alpha coefficients of the 15 items are 0.85 to 0.91 , of which the alpha coefficient of the subject interest subscale is 0.82 to 0.86 , and the alpha coefficient of the teaching interest subscale is 0.70 to 0.82 . The alpha coefficient of the educational interest subscale is 0.80 to 0.91 .

In this survey, the Cronbach's Alpha coefficient of 15 items was 0.834 , of which the alpha coefficient of the subject interest subscale was 0.895 , the alpha coefficient of the teaching interest subscale was 0.853 , and the alpha coefficient of the educational interest subscale was 0.938 , and the data shows that the reliability of each dimension is good.

\section{Career Choice Satisfaction (CCS)}

The career choice satisfaction scale (a subscale of the Fit-Choice scale, Watt \& Richardson, 2007) was used to evaluate the satisfaction of pre-service teachers with their teaching choices. This scale contains three items (how satisfied are you with your choice to become a teacher? How happy are you with your decision to become a teacher? How carefully did you consider becoming a teacher?), adopt Likert 7-level scoring method, from 1 (nothing at all) to 7 (extremely), the higher the score, the higher the degree of career choice satisfaction. 
Previous studies have shown that the CCS scale with three items is an effective and reliable indicator for measuring pre-service teachers' career choices satisfaction (Eren \& Tezel, 2010). In this study, the Cronbach's Alpha coefficient of the scale is calculated to be 0.824 , which has good reliability.

\section{Results}

There are 21items in the questionnaire(including demographic information). All data are processed and analyzed using SPSS 22 version, and descriptive statistics and inferential statistics results are obtained. Here will be divided into three sub-topics for discussion, namely; (1) Comparison from Gender, internship experience and grade in each dimension; (2) the profile of Pre-service preschool teachers' subject interest, didactic interest, educational interest and career choice satisfaction ; (3) The relationship between the various dimensions of pre-service preschool teachers' interest and career choice satisfaction.

\section{Comparison Between Gender}

There are 201 respondents involved in this survey. 23 males and 178 females had been responded to this questionnaire. The data shows the results of the independent t-test for the first null hypothesis. The p-value for Levene's Test is $0.043,0.002,0.014$ separately in the dimension of $\mathrm{SI}, \mathrm{EI}, \mathrm{CCS}$, which is less than $.05(\mathrm{p}<.05)$; The $\mathrm{p}$-value for Levene's Test is 0.094 in the dimension of $\mathrm{DI}$, which is more than .05 ( $p>.05)$. Therefore, the null hypothesis1 is partly rejected.

To summarize, there is a significant difference for pre-service preschool teachers' different genders in subject interest, educational interest and career choice satisfaction; There is no significant difference for different genders' pre-service preschool teachers' in didactic interest.

The average mean score for level of subject interest of female preschool teachers $(M=3.997)$ is higher than that of male preschool teachers $(M=3.477)$; The average mean score for level of educational interest of female preschool teachers $(M=4.564)$ is higher than that of educational interest of male preschool teachers $(M=3.894)$; The average mean score for level of career choice satisfaction with female preschool teachers $(M=3.828)$ is higher than that of career choice satisfaction with male preschool teachers $(M=3.500)$

\section{Comparison Between Internship Experience or not}

In this study, there are 83 people who have internship experience and 118 people have no internship experience. The data shows the results of the independent t-test for the second null hypothesis. The $p$-value for Levene's Test is $0.319,0.140$ separately in the dimension of $\mathrm{SI}, \mathrm{DI}$, which is more than .05 ( $p>.05$ ); The $p$-value for Levene's Test is $0.001,0.000$ in the dimension of $\mathrm{El}, \mathrm{CCS}$, which is less than $.05(\mathrm{p}<.05)$. Therefore, null hypothesis 2 is partly rejected.

To summarize, there is no significant difference for pre-service preschool teachers with internship experience in subject interest and didactic interest; There is a significant difference for pre-service preschool teachers without internship experience in educational interest and career choice satisfaction;

The average mean score for level of educational interest of pre-service teachers without internship experience $(M=4.659)$ is higher than that of pre-service teachers with internship experience $(M=4.335)$; The average mean score for level of career choice satisfaction of 
DEVELOPMENT

Vol. 11, No. 1, 2022, E-ISSN: 2226-6348 @ 2022 HRMARS

preschool teachers without internship experience $(M=4.009)$ is higher than that of pre-service preschool teachers without internship experience $(M=3.582)$

\section{Comparison Between Grades}

In this study, 65 freshmen, 53 sophomores, 46 juniors and 37 seniors were investigated. The data shows the results of ANOVA for the third null hypothesis. The $p$-value is $0.634,0.528$ separately in the dimension of $\mathrm{SI}, \mathrm{DI}$, which is more than .05 ( $p>.05)$; The $p$-value is $0.000,0.000$ in the dimension of $\mathrm{El}, \mathrm{CCS}$, which is less than $.05(\mathrm{p}<.05)$. Therefore, null hypothesis 3 is partly rejected.

As a Conclusion, There is no significant difference for pre-service preschool teachers of different grades in subject interest, didactic interest; There is a significant difference for pre-service preschool teachers of different grades in educational interest and career choice satisfaction;

The average mean score for the level of educational interest of freshmen is significantly higher than that of junior and senior (Mean Difference $=0.528^{*}, 0.409^{*}$ ). The average mean score for level of educational interest of the sophomore was significantly higher than that of junior and senior (Mean Difference $=0.693 *, 0.571 *$ ). The average mean score for the level of satisfaction with freshmen is significantly higher than that of junior and senior (Mean Difference=1.179*, $0.754 *)$

The average mean score for level of satisfaction with the career choice of the sophomore was significantly higher than that of junior and senior (Mean Difference $=1.761^{*}, 0.751^{*}$ )

The Profile of Pre-service Preschool Teachers' Subject Interest, Didactic Interest, Educational Interest and Career Choice Satisfaction

This study found that the level of interest of the subjects in descending order is DI (5.015 \pm 1.050$)$, El $(4.495 \pm 1.063)$, SI $(3.943 \pm 1.296)$; the average value of satisfaction with the subject's occupational choice $3.794 \pm 0.909$.

Table 1

\begin{tabular}{llllll}
\hline & N & Minimum & Maximum & Mean & Std. Deviation \\
\hline SI & 201 & 1 & 7 & 3.943 & 1.296 \\
DI & 201 & 1 & 7 & 5.015 & 1.050 \\
EI & 201 & 1 & 7 & 4.495 & 1.063 \\
CCS & 201 & 1 & 6 & 3.794 & 0.909 \\
\hline
\end{tabular}

Relationship between Pre-service Preschool Teachers' Interest and Career Choice Satisfaction

Table 2 shows that the subject interest of pre-service preschool teachers is significantly positively correlated with didactic interest and educational interest $\left(r=0.127^{* *}, 0.151^{* *}\right)$. The educational interest of pre-service preschool preschool teachers was significantly positively correlated with didactic interest and career choice satisfaction $\left(r=0.458^{* *}\right.$, $\left.0.160^{* *}\right)$. Hence, null hypothesis 4 is partly rejected. 
Table 2 Correlations

\begin{tabular}{|c|c|c|c|c|c|}
\hline & & $\mathrm{SI}$ & $\mathrm{DI}$ & $\mathrm{EI}$ & CCS \\
\hline SI & $\begin{array}{l}\text { Pearson Correlation } \\
\text { Sig. (2-tailed) }\end{array}$ & 1 & & & \\
\hline DI & $\begin{array}{l}\text { Pearson Correlation } \\
\text { Sig. (2-tailed) }\end{array}$ & $\begin{array}{l}.127 * * \\
0.004\end{array}$ & 1 & & \\
\hline El & $\begin{array}{l}\text { Pearson Correlation } \\
\text { Sig. (2-tailed) }\end{array}$ & $\begin{array}{l}.151 * * \\
0.001\end{array}$ & $\begin{array}{l}.458 * * \\
0\end{array}$ & 1 & \\
\hline CCS & $\begin{array}{l}\text { Pearson Correlation } \\
\text { Sig. (2-tailed) }\end{array}$ & $\begin{array}{l}-0.004 \\
0.934\end{array}$ & $\begin{array}{l}-0.02 \\
0.659\end{array}$ & $\begin{array}{l}.160 * * \\
0\end{array}$ & 1 \\
\hline
\end{tabular}

** Correlation is significant at the 0.01 level (2-tailed).

\section{Discussion}

It is both reasonable and important to examine the interest of pre-service teachers. By doing so, teacher educators can understand pre-service teachers' interests more comprehensively and accurately (Eren, 2012)

\section{Demographic Information on Teachers' Interest and Career Choice Satisfaction}

According to the level of gender influence on pre-service preschool teachers' subject interest, teaching interest, educational interest and career choice satisfaction, it is found that the mean value of female teachers' subject interest, educational interest and career choice satisfaction is higher than that of male teachers and is significant; There is no significant difference in didactic interest among pre-service preschool teachers of different genders. This difference is also not found in previous studies. This finding is also more in line with the current social situation. In traditional Chinese concepts, people think that women are more suitable for a job like a teacher. Therefore, under the influence of important others in society, women are more willing to engage in the profession of kindergarten teacher, and are relatively more interested in the subject of preschool education. With this more patient and careful character, female pre-service preschool teachers will be more likely to accept the content and knowledge of the teaching and prepare for how to build their career in the future.

In addition, the average values of educational interest and career choice satisfaction of preservice preschool teachers without internship experience are significantly higher than those of pre-service preschool teachers with internship experience, and there are significant differences.

There are no significant differences in subject interest and teaching interest among teachers with or without internship experience; At present, there is no research on the influence of internship experience on teachers' interest. However, previous studies have shown that preservice teachers without internship experience are significantly more satisfied with their career choices than those with internship experience (Guo \& Sun, 2018; Dan et al., 2018) Furthermore, the average value of the educational interest and career choice satisfaction of the first-year and second-year pre-service preschool teachers is significantly higher than that of the third year, and the average value of the educational interest of the pre-service preschool teachers of the senior year and there are significant statistical differences.

However, preschool teachers of different grades have no statistical difference in subject interest and teaching interest. This discovery is closely related to the previous discovery. In the current preschool internship mechanism in China, freshmen and sophomores need to spend 
more time on learning knowledge and subject content. In the third and fourth year of college, collegees will increase the times and lengths of internships and internship opportunities, which lead to less time in learning knowledge and content. Therefore, Since teachers with no internship experience are more satisfied with their educational interests and career choices, it is very consistent with the result that the educational interests and career choices of freshmen and sophomores are also higher than those of juniors and seniors.

\section{The Level of Teachers' Interests and Career Choice Satisfaction}

This study found that the level of teacher interests was DI (5.015 \pm 1.050$)$, El (4.495 \pm 1.063$)$, and SI $(3.943 \pm 1.296)$. The mean value of career choice satisfaction is $3.794 \pm 0.909$, which is not consistent with the results of the existing literature (Eren, 2010) on the survey of pre-service English teachers in Turkey. This may be due to the differences in the survey samples and countries. Turkey has a highly concentrated university entrance examination and lacks career guidance services in high school education. The placement of preservice teachers in Turkey is not based on students' interests, but mainly on their test scores.

Therefore, Such a placement system, coupled with the lack of career guidance services in high schools, may cause students to choose career trajectories that they do not expect, such as engaging in teaching, which in turn negatively affects future teachers' interest in teaching (Kuzgun, 2009).

In China, high school students can freely choose the subjects they want to study after taking the university entrance examination. Therefore, they will choose the pre-service preschool teacher profession. The average value of interest and subject interest will be higher.

\section{Relationships between Teacher's Interests and Career Choice Satisfaction}

Table 2 shows that the subject interest of pre-service teachers is significantly positively correlated with ditactic interest and educational interest $\left(r=0.127^{* *}, 0.151^{* *}\right)$; The educational interest of pre-service preschool teachers was significantly positively correlated with ditactic interest and career choice satisfaction $\left(r=0.455^{* *}, 0.160^{* *}\right)$.

The results of this study also show that the ditactic interest of pre-service preschool teachers is significantly related to their career choice satisfaction. A recent study of pre-service English teachers in Turkey also obtained similar results (Eren \& Tezel, 2010). The results show that subject interest has the greatest correlation with career choice satisfaction, and the relationship between career choice satisfaction and subject interest $(r=0.58)$, ditactic interest $(r=0.45)$, and education interest $(r=0.49)$ are substantial and positive. This is also consistent with the results of previous studies (Streblow et al., 2013).

In summary, these studies on the correlation of the four dimensions provide a basis for understanding why future teachers' interest and career choice satisfaction have significant positive relationships at different levels.

\section{Limitations of the Study}

Due to the small sample, it is impossible to analyze in more detail about the influence of demographic factors such as different locations and ages on teachers' interest and career choice satisfaction; and no attempt has been made on the mediating and moderating variables that may participate in it. In the future, it is necessary to further accumulate and expand data, To add important variables, broaden the research horizon, and conduct research from the 
DEVELOPMENT

Vol. 11, No. 1, 2022, E-ISSN: 2226-6348 @ 2022 HRMARS

perspective of pre-service preschool teachers to provide references for the selection and training of preschool teachers.

\section{Conclusion}

This study investigated the perception of pre-service and preschool teachers' career choice satisfaction. The results show that the subject interest of pre-service preschool teachers was significantly positively correlated with didactic interest and educational interest; educational interest was significantly positively correlated with didactic interest and career choice satisfaction. This research has made an in-depth understanding of the relationship between pre-service preschool teachers' interests and career choice satisfaction, and has made contributions to the knowledge system and research on teacher interest and career choice satisfaction. This research will also increase society's awareness of preschool teachers' interest in teaching, and show that it is meaningful to pay attention to the teachers' career choice satisfaction to clarify the important reasons for the loss of preschool teachers.

Therefore, for the sake of the satisfaction of pre-service preschool teachers' career choices, and to reduce the turnover rate of kindergarten teachers, the interest of pre-service teachers can be listed as an important influencing factor. Specifically, first of all, the social and educational departments should optimize the treatment of teachers and the working environment, improve the opportunities for high school students to choose pre-school education as a major, and promote the maintenance and improvement of interest in subjects after enrollment in the university; Secondly, in the preschool education curriculum of colleges and universities, we should optimize the curriculum mechanism, pay attention to the teaching of teaching methods, and improve the self-efficacy and didactic interest of pre-service and preschool teachers. Finally, universities or colleges should regularly carry out education on students' thoughts and values to improve pre-service preschool teachers' ideological and ethical construction, which will provide the self-adjustment ability for future preschool teachers.

\section{Acknowledgment}

This work was supported by the Fujian Provincial Education Department's Young and Middleaged Teacher Education Research Project "Research on the Influencing Factors of Pre-service Preschool Teachers' Career Choice: A FIT-CHOICE Theoretical Perspective" (JAS19372).

\section{References}

Eren, A. (2012). Prospective teachers' interest in teaching, professional plans about teaching and career choice satisfaction: A relevant framework?. Australian Journal of Education, 56(3), 303-318.

Eren, A., \& Rakıcıoğlu-Söylemez, A. (2017). Pre-service teachers' ethical stances on unethical professional behaviors: The roles of professional identity goals and efficacy beliefs. Teaching and Teacher Education, 68, 114-126.

Eren, A., \& Tezel, K. V. (2010). Factors influencing teaching choice, professional plans about teaching, and future time perspective: A mediational analysis. Teaching and Teacher Education, 26(7), 1416-1428.

Glutsch, N., \& König, J. (2019). Pre-service teachers' motivations for choosing teaching as a career: does subject interest matter?. Journal of Education for Teaching, 45(5), 494-510. 
Harackiewicz, J. M., Durik, A. M., Barron, K. E., Linnenbrink-Garcia, L., \& Tauer, J. M. (2008). The role of achievement goals in the development of interest: reciprocal relations between achievement goals, interest, and performance. Journal of educational psychology, 100(1), 105.

Hennessy, J., \& Lynch, R. (2017). "I chose to become a teacher because". Exploring the factors influencing teaching choice amongst pre-service teachers in Ireland. Asia-Pacific Journal of Teacher Education, 45(2), 106-125.

Kılınç, A., Watt, H. M., \& Richardson, P. W. (2012). Factors influencing teaching choice in Turkey. Asia-Pacific Journal of Teacher Education, 40(3), 199-226.

Kuzgun, I. (2009). The parameters affecting labor management consultation process in Turkey: case of Turkey. Problems and perspectives in management, (7, Iss. 3), 104-111.

Long, J. F., \& Hoy, A. W. (2006). Interested instructors: A composite portrait of individual differences and effectiveness. Teaching and Teacher Education, 22(3), 303-314.

Musu-Gillette, L. E., Wigfield, A., Harring, J. R., \& Eccles, J. S. (2015). Trajectories of change in students' self-concepts of ability and values in math and college major choice. Educational Research and Evaluation, 21(4), 343-370.

Richardson, P. W., \& Watt, H. M. (2006). Who chooses teaching and why? Profiling characteristics and motivations across three Australian universities. Asia-Pacific Journal of Teacher Education, 34(1), 27-56.

Richardson, P. W., \& Watt, H. M. (2006). Who chooses teaching and why? Profiling characteristics and motivations across three Australian universities. Asia-Pacific Journal of Teacher Education, 34(1), 27-56.

Schiefele, U. (2017). Classroom management and mastery-oriented instruction as mediators of the effects of teacher motivation on student motivation. Teaching and teacher education, 64, 115-126.

Schiefele, U., \& Schaffner, E. (2015). Teacher interests, mastery goals, and self-efficacy as predictors of instructional practices and student motivation. Contemporary Educational Psychology, 42, 159-171.

Schiefele, U., Streblow, L., \& Retelsdorf, J. (2013). Dimensions of teacher interest and their relations to occupational well-being and instructional practices. Journal for educational research online, 5(1), 7-37.

Watt, H. M., \& Richardson, P. W. (2007). Motivational factors influencing teaching as a career choice: Development and validation of the FIT-Choice scale. The Journal of experimental education, 75(3), 167-202.

Watt, H. M., \& Richardson, P. W. (2008). Motivations, perceptions, and aspirations concerning teaching as a career for different types of beginning teachers. Learning and instruction, 18(5), 408-428.

$\mathrm{Li}, \mathrm{Z}$. (2011). Comparative study on the professional interest of prospective preschool teachers at all levels in Guangdong Province. Education Guide (04), 31-33. 